\title{
Isolation and Full-Genome Characterization of Nipah Viruses from Bats, Bangladesh
}

\section{Danielle E. Anderson, ${ }^{1}$ Ariful Islam, ${ }^{1}$ \\ Gary Crameri, ${ }^{1}$ Shawn Todd, Ausraful Islam, Salah U. Khan, Adam Foord, Mohammed Z. Rahman, Ian H. Mendenhall, Stephen P. Luby, Emily S. Gurley, Peter Daszak, Jonathan H. Epstein, ${ }^{1}$ Lin-Fa Wang ${ }^{1}$}

Despite molecular and serologic evidence of Nipah virus in bats from various locations, attempts to isolate live virus have been largely unsuccessful. We report isolation and full-genome characterization of 10 Nipah virus isolates from Pteropus medius bats sampled in Bangladesh during 2013 and 2014.

$\mathrm{N}$ ipah virus $(\mathrm{NiV})$ is an emerging zoonotic virus carried by bats. It is considered a global health priority by the World Health Organization and has pandemic potential because of its zoonotic nature, human-to-human transmissibility, wide geographic distribution of bat reservoir species, high case-fatality rate in humans, and lack of available vaccine or therapeutic agents (1). Although NiV or NiV-related infections have been demonstrated by serologic surveillance or PCR detection in several bat species across extensive areas, attempts to isolate live $\mathrm{NiV}$ have been unsuccessful; there have been only 3 successful reports: Pteropus hypomelanus bats (2) and P. vapmyrus bats (3) in Malaysia and P. lylei bats in Cambodia (4).

Bangladesh has reported seasonal outbreaks of infectious NiV almost annually since 2001, and India has reported 2 outbreaks in neighboring West Bengal, the last in 2007 (5,6). In May 2018, India reported an outbreak in Kerala State, which is $>1,800 \mathrm{~km}$ southwest of West Bengal

Author affiliations: Duke-National University of Singapore Medical School, Singapore (D.E. Anderson, I.H. Mendenhall, L.-F. Wang); EcoHealth Alliance, New York, New York, USA (Ariful Islam,

P. Daszak, J.H. Epstein); CSIRO Australian Animal Health Laboratory, Geelong, Victoria, Australia (G. Crameri, S. Todd, A. Foord); icddrb, Dhaka, Bangladesh (Ausraful Islam,

M.Z. Rahman, E.S. Gurley); University of Guelph, Guelph, Ontario, Canada (S.U. Khan); Stanford University, Stanford, California, USA (S.P. Luby); Johns Hopkins Bloomberg School of Public Health, Baltimore, Maryland, USA (E.S. Gurley) (https://www.searo.who.int/entity/emerging_diseases/links/ nipah_virus_outbreaks_sear/en).

Despite sustained efforts to detect $\mathrm{NiV}$ in bats in this region, current infection data are largely from serologic and limited PCR detection of virus RNA from potential bat reservoirs, such as $P$. medius from Bangladesh and India (7-10). $\mathrm{NiV}$ genomic data from the region have come primarily from human cases $(11,12)$. Spillover might not be limited to humans in Bangladesh; nonneutralizing antibodies against $\mathrm{NiV}$ in cattle, goats, and pigs (13) underscore the urgency of characterizing diversity of henipaviruses in $P$. medius bats and other possible animal reservoirs in the region.

We report isolation of NiVs from P. medius bats in Bangladesh. We performed full-genome characterization of these viruses by using enrichment-based next-generation sequencing (NGS).

\section{The Study}

During January 2011-April 2014, we collected 2,749 bat samples from various ongoing projects in the region. We collected samples nondestructively from individual bats as described (7) and collected environmental urine samples from underneath roosts by using polyethylene sheets. In early 2013, an outbreak of infection with NiV occurred in 13 districts of Bangladesh (Gaibandha, Jhinaidaha, Kurigram, Kushtia, Magura, Manikganj, Mymenshingh, Naogaon, Natore, Nilphamari, Pabna, Rajbari, and Rajshahi). In April 2013, we collected only urine samples during an outbreak investigation in Raipur, Manikganj. We also tested 944 underroost urine samples, 829 throat swab specimens, and 976 urine samples from 2 confirmed bat species $(P$. medius and Rousettus leschenaultia) for NiV. Samples were collected with permission from the Government of Bangladesh Forestry Office and under Institutional Animal Care and Use Committees (Tufts University no. G2011-12 and University of California at Davis no. 19300).

We also collected bat samples from 5 sites in Raipur that showed NiV spillover and 1 district (Sylhet) that had no reported cases (Figure 1). Samples were tested at the CSIRO Australian Animal Health Laboratory under BioSafety Level 4 containment. Individual samples were pooled into groups of 4 for initial extraction and PCR analysis. Of 688 pooled samples tested, 20 pools were positive by a nucleoprotein gene-specific 1-step reverse transcription

\footnotetext{
${ }^{1}$ These authors contributed equally to this article.
} 


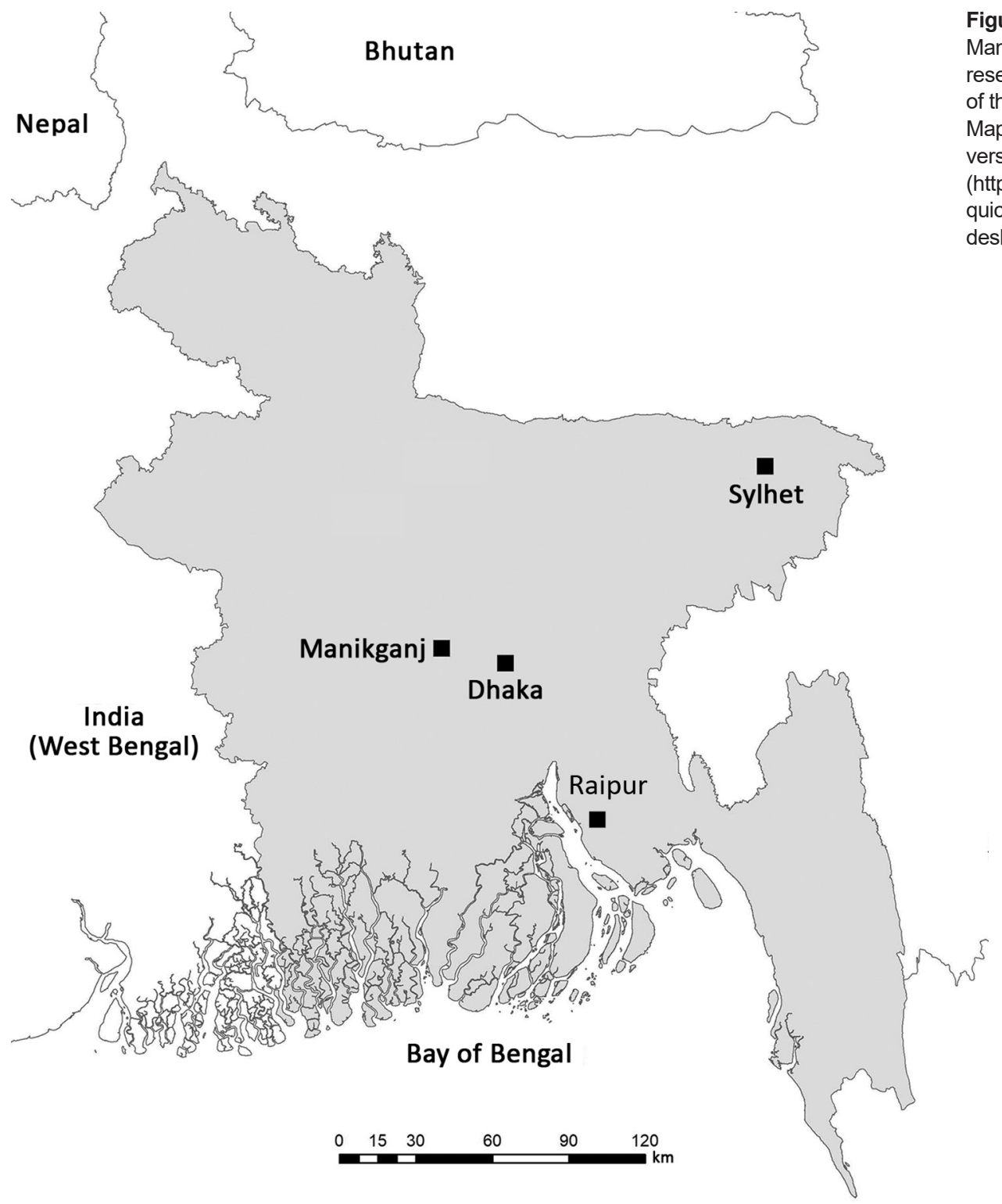

Figure 1. Sampling sites (Raipur, Manikganj, and Sylhet) for bat reservoirs of Nipah virus and location of the capital, Dhaka, in Bangladesh. Map was generated by using ArcGIS version 10.4.1 software (https://desktop.arcgis.com/en/ quick-start-guides/10.4/arcgisdesktop-quick-start-guide.htm).

quantitative PCR. The 80 individual samples from positive pools were thawed for virus isolation and RNA reextracted for PCR. Of 80 samples (urine and throat swab specimens) tested by nucleoprotein gene-gene specific 1-step reverse transcription quantitative PCR, only 20 urine samples were positive. We used these 20 urine samples for virus isolation.

We performed virus isolation under BioSafety Level 4 containment. For virus isolation from PCR-positive samples, we prepared Vero cells in 96-well plates in Eagle minimum essential medium (EMEM) containing 10\% fetal bovine serum and $1 \times$ antibiotic-antimycotic mixture (GIBCO, http://www.biosciences.ie/gibco). We added 50 $\mu \mathrm{L}$ of each sample to 2 wells, incubated each sample for $90 \mathrm{~min}$, remove the inoculum, and added $200 \mu \mathrm{L}$ EMEM to each well. Plates were incubated at $37^{\circ} \mathrm{C}$, checked at 7 days postinfection for a cytopathic effect (CPE), and frozen at $-80^{\circ} \mathrm{C}$.

A total of 11 wells showed CPE, and putative virus culture from these wells was passaged a second time by inoculation of a 24 -well plate containing $80 \%$ confluent Vero cells in EMEM with $80 \mu \mathrm{L}$ of culture supernatant from each positive well. Plates were incubated at $37^{\circ} \mathrm{C}$ for $90 \mathrm{~min}$; inoculum was removed and $1 \mathrm{~mL}$ EMEM added. Plates were then incubated at $37^{\circ} \mathrm{C}$ for 5 days. All 11 samples remained CPE positive after this second passage.

For a third passage, we harvested culture supernatant and added $300 \mu \mathrm{L}$ to a $25-\mathrm{cm}$ flask containing $80 \%$ confluent Vero cells. Flasks were incubated for $90 \mathrm{~min}$ at $37^{\circ} \mathrm{C}$ before inoculum was removed and $5 \mathrm{~mL}$ EMEM added. We incubated the flasks at $37^{\circ} \mathrm{C}$ and harvested 


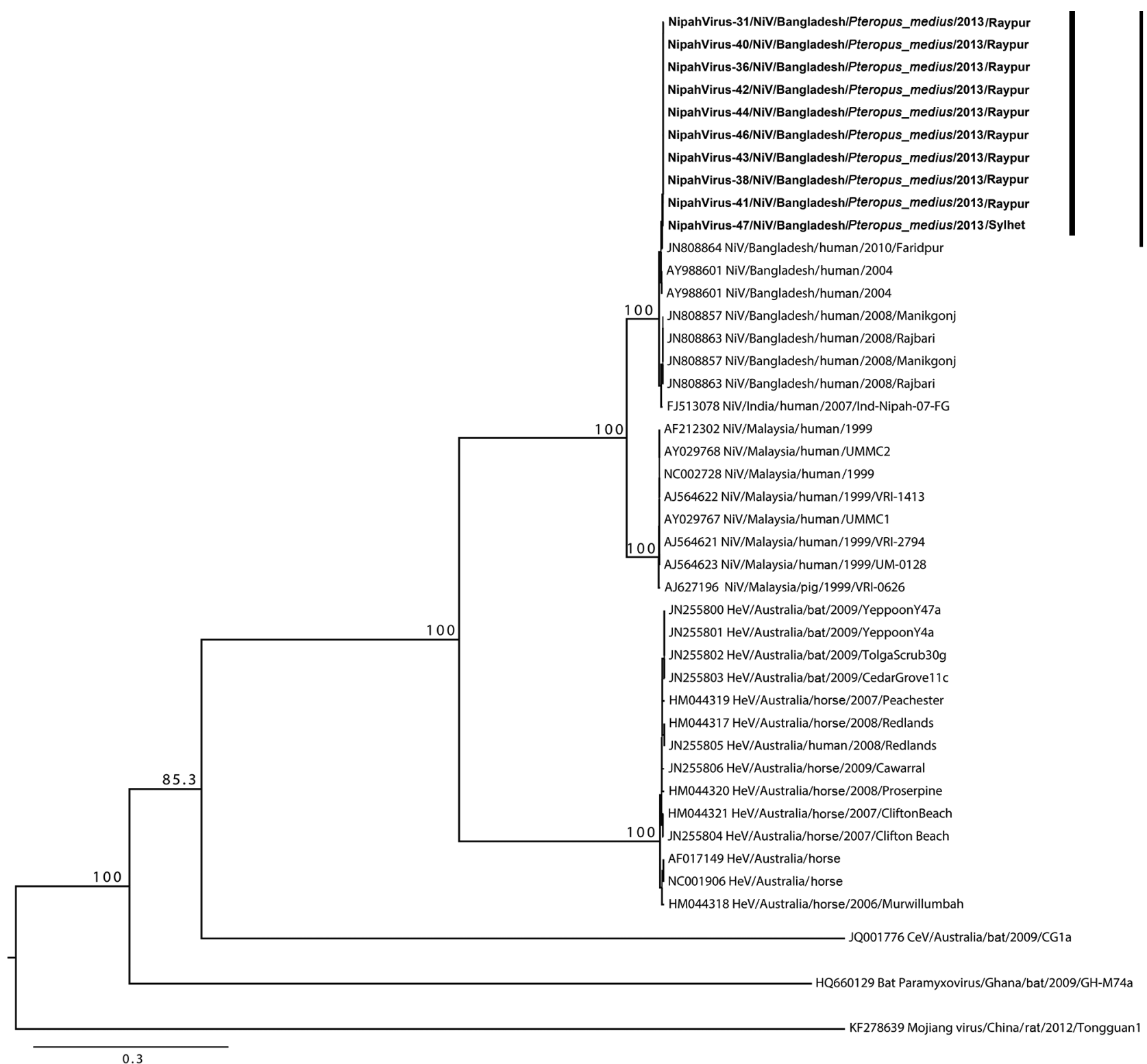

Figure 2. Phylogenetic tree of Nipah viruses from bats in Bangladesh (bold) compared with other henipaviruses, generated from full-genome sequences. Tree was constructed by using a maximum-likelihood approach, and robustness of nodes was tested with 1,000 bootstrap replicates. Sequences are labeled according to the following ordination: GenBank accession number or isolate identification number/virus type/country/host/year/strain. Numbers along branches are bootstrap values. Scale bar indicates nucleotide substitutions per site.

virus supernatants at $2-3$ days postinfection. Supernatants were clarified by centrifugation at $10,000 \times g$ for $5 \mathrm{~min}$ and frozen at $-80^{\circ} \mathrm{C}$.

To confirm the identity of isolated viruses, we subjected each sample to electron microscopy and PCR. All isolates had morphology consistent with $\mathrm{NiV}$ and were positive by NiV-specific PCR. Virus stocks were amplified in Vero cells, and supernatants were harvested and clarified by centrifugation at $10,000 \times g$ for $10 \mathrm{~min}$, followed by pelleting virus from supernatant by centrifugation at
$200,000 \times g$ for $30 \mathrm{~min}$. Virus pellets were resuspended in $200 \mu \mathrm{L}$ of Magmax Buffer (Applied Biosystems, https:// www.thermofisher.com/us/en/home/brands/applied-biosystems.html) for RNA extraction according to the manufacturer's protocol.

We used a virus enrichment strategy (14) to obtain the full-genome sequence for $\mathrm{NiV}$ isolates. Total RNA was used to prepare NGS libraries (New England Biolabs, https://www.neb.com) according to the manufacturer's instructions. DNA libraries were subjected to a liquid-based 
Table. Characteristics of 11 bat samples tested for Nipah virus, Bangladesh*

\begin{tabular}{|c|c|c|c|c|c|c|c|}
\hline Sample no. & Sample ID & $\begin{array}{c}\text { Date } \\
\text { sampled }\end{array}$ & Location & Sample type* & $\begin{array}{l}\text { Taqman } \\
\text { PCR } C_{t}\end{array}$ & NGS & Isolate designation \\
\hline 1 & PGB-1401B & 2011 Apr 13 & Raipur, Manikganj & ORU & 31.9 & Yes & NiV/BD/BA/2013/Raipur1401 \\
\hline 2 & PGB-1402B & 2011 Apr 13 & Raipur, Manikganj & ORU & 30.1 & Yes & NiV/BD/BA/2013/Raipur1402 \\
\hline 3 & PGB-1403B & 2011 Apr 13 & Raipur, Manikganj & ORU & 31.0 & Yes & NiV/BD/BA/2013/Raipur1403 \\
\hline 4 & PGB-1404B & 2011 Apr 13 & Raipur, Manikganj & ORU & 31.3 & Yes & NiV/BD/BA/2013/Raipur1404 \\
\hline 5 & PGB-1405B & 2011 Apr 13 & Raipur, Manikganj & ORU & 31.0 & Yes & NiV/BD/BA/2013/Raipur1405 \\
\hline 6 & PGB-1406B & 2011 Apr 13 & Raipur, Manikganj & ORU & 31.9 & Yes & NiV/BD/BA/2013/Raipur1406 \\
\hline 7 & PGB-1408B & 2011 Apr 13 & Raipur, Manikganj & ORU & 31.3 & Yes & NiV/BD/BA/2013/Raipur1408 \\
\hline 8 & PGB-1409B & 2011 Apr 13 & Raipur, Manikganj & ORU & 31.7 & Yes & NiV/BD/BA/2013/Raipur1409 \\
\hline 9 & PGB-1410B & 2011 Apr 13 & Raipur, Manikganj & ORU & 31.0 & Yes & NiV/BD/BA/2013/Raipur1410 \\
\hline 10 & PGB-1411B & 2011 Apr 13 & Raipur, Manikganj & ORU & 30.8 & No & NiV/BD/BA/2013/Raipur1411 \\
\hline 11 & PGB-191 & 2006 Jan 13 & Sylhet & $\mathrm{RU}$ & 39.0 & Yes & NiV/BD/BA/2013/Sylhet191 \\
\hline
\end{tabular}

target capture method to separate and enrich for specific NiV sequences. NiV-specific 120-mer biotinylated DNA baits were designed to capture the entire genome. Hybridized probes and captured $\mathrm{NiV}$ genetic material were immobilized on magnetic beads, and contaminating host material was washed away, which increased the number of virus-specific reads. We mapped all reads to NiV sequence JN808863 by using the Map to Reference Function in Geneious version 7.1.6 (https://www.geneious.com/previous-versions). The consensus nucleotide sequence was selected by majority rules at each site.

To ascertain $5^{\prime}$ and $3^{\prime}$ ends because of low coverage and PCR errors and chimeras, we downloaded full-genome NiV sequences from GenBank and aligned them by using MAFFT in Geneious. A 90\% similarity threshold was used to generate consensus $5^{\prime}$ and $3^{\prime}$ sequences of 120 nt. Final consensus full genomes had $10 \times$ coverage. We downloaded full-genome henipaviruses from GenBank, generated alignment by using the MAFFT plugin in Geneious, and tested node robustness by using 1,000 bootstrap replicates under the general time reversible plus gamma model in PHYML (15).

Full-length genome sequences were obtained from 10 bat NiV isolates. We constructed a phylogenetic tree (Figure 2) that showed all bat isolates had nearly identical genome sequences; there was $99.9 \%$ conservation among all 10 genomes characterized (Table). The virus isolated in Sylhet during January 2013 was nearly identical to all other isolates obtained in 2013 in Raipur, which is $\approx 350$ $\mathrm{km}$ from Sylhet, suggesting that NiV homogeneity might be supported by bat movements connecting disparate bat colonies (10).

\section{Conclusions}

We report isolation of $\mathrm{NiV}$ from $P$. medius bats, a natural virus reservoir in Bangladesh. With an improved enrichment-based NGS strategy, we generated complete genome sequences for 10 bat $\mathrm{NiV}$ isolates with higher efficiency than for traditional PCR-based sequencing methods. NiV has been difficult to isolate from bats and, similar to results of previous studies of Hendra virus (10), we observed that successful virus isolation does not correlate with cycle thresholds. The complete sequence identity match among isolates obtained during the outbreak investigation in Raipur suggests that multiple strains were not co-circulating in the bat population at the time, supporting results of a previous study in Faridpur (10).

None of the bat $\mathrm{NiV}$ isolate sequences were identical with any previously detected human $\mathrm{NiV}$ isolate sequences, suggesting that $\mathrm{NiV}$ spillover into humans is a rare event. However, the genetic diversity of bat $\mathrm{NiV}$ isolates needs to be fully identified.

\section{Acknowledgments}

We thank Ina Smith and Vicky Boyd for providing assistance and support during this study, Sandy Crameri for performing the electron microscopy, and Jordan Menscher for his help collecting bat roost urine samples. We also thank the Forest Department, Government of Bangladesh, for their support and for providing permission and the appropriate permits to conduct the study.

This study was supported by the National Institutes of Health Fogarty International Center (R01TW005869: P.D., J.H.E., A.I., S.P.L., and E.S.G.), the US Agency for International Development, PREDICT Project (J.H.E., A.I., A.I., and P.D.), and a National Science Foundation Research Coordination Network Award (EcoHealthNet DEB-0955897). L.-F. W. was supported by the National Research Foundation (NRF2012NRF-CRP001-056), the Ministry of Health (CDPHRG/0006/2014) and the Ministry of Defence (DIRP2015-9016102060) in Singapore. D.E.A. and I.H.M. were supported by New Investigators Grants from the National Medical Research Council of Singapore (NMRC/BNIG/2030/2015 and NMRC/BNIG/2005/2013).

\section{About the Author}

Dr. Anderson is a virologist at Duke-National University of Singapore Medical School, Singapore. Her research interests are paramyxovirus pathogenesis and pathogen discovery by using novel molecular and serologic approaches. 


\section{References}

1. Sweileh WM. Global research trends of World Health Organization's top eight emerging pathogens. Global Health. 2017;13:9. http://dx.doi.org/10.1186/s12992-017-0233-9

2. Chua KB, Koh CL, Hooi PS, Wee KF, Khong JH, Chua BH, et al. Isolation of Nipah virus from Malaysian Island flying-foxes. Microbes Infect. 2002;4:145-51. http://dx.doi.org/10.1016/ S1286-4579(01)01522-2

3. Rahman SA, Hassan SS, Olival KJ, Mohamed M, Chang L-Y, Hassan L, et al.; Henipavirus Ecology Research Group. Characterization of Nipah virus from naturally infected Pteropus vampyrus bats, Malaysia. Emerg Infect Dis. 2010;16:1990-3. http://dx.doi.org/10.3201/eid1612.091790

4. Reynes JM, Counor D, Ong S, Faure C, Seng V, Molia S, et al. Nipah virus in Lyle's flying foxes, Cambodia. Emerg Infect Dis. 2005;11:1042-7. http://dx.doi.org/10.3201/eid1107.041350

5. Chadha MS, Comer JA, Lowe L, Rota PA, Rollin PE, Bellini WJ, et al. Nipah virus-associated encephalitis outbreak, Siliguri, India. Emerg Infect Dis. 2006;12:235-40. http://dx.doi.org/10.3201/ eid1202.051247

6. Hahn MB, Gurley ES, Epstein JH, Islam MS, Patz JA, Daszak P, et al. The role of landscape composition and configuration on Pteropus giganteus roosting ecology and Nipah virus spillover risk in Bangladesh. Am J Trop Med Hyg. 2014;90:247-55. http://dx.doi.org/10.4269/ajtmh.13-0256

7. Epstein JH, Prakash V, Smith CS, Daszak P, McLaughlin AB, Meehan G, et al. Henipavirus infection in fruit bats (Pteropus giganteus), India. Emerg Infect Dis. 2008;14:1309-11. http://dx.doi.org/10.3201/eid1408.071492

8. Hsu VP, Hossain MJ, Parashar UD, Ali MM, Ksiazek TG, Kuzmin I, et al. Nipah virus encephalitis reemergence, Bangladesh. Emerg Infect Dis. 2004;10:2082-7. http://dx.doi.org/10.3201/eid1012.040701

9. Yadav PD, Raut CG, Shete AM, Mishra AC, Towner JS, Nichol ST, et al. Detection of Nipah virus RNA in fruit bat (Pteropus giganteus) from India. Am J Trop Med Hyg. 2012;87:576-8. http://dx.doi.org/10.4269/ajtmh.2012.11-0416

10. Epstein JH. The ecology of Nipah virus and the first identification of a bat Pegivirus in Pteropus medius, Bangladesh. London: Kingston University; 2017

11. Lo MK, Lowe L, Hummel KB, Sazzad HMS, Gurley ES, Hossain MJ, et al. Characterization of Nipah virus from outbreaks in Bangladesh, 2008-2010. Emerg Infect Dis. 2012;18:248-55. http://dx.doi.org/10.3201/eid1802.111492

12. Arankalle VA, Bandyopadhyay BT, Ramdasi AY, Jadi R, Patil DR, Rahman M, et al. Genomic characterization of Nipah virus, West Bengal, India. Emerg Infect Dis. 2011;17:907-9. http://dx.doi.org/10.3201/eid1705.100968

13. Chowdhury S, Khan SU, Crameri G, Epstein JH, Broder CC, Islam A, et al. Serological evidence of henipavirus exposure in cattle, goats and pigs in Bangladesh. PLoS Negl Trop Dis. 2014;8:e3302. http://dx.doi.org/10.1371/journal.pntd. 0003302

14. Ho ZJ, Hapuarachchi HC, Barkham T, Chow A, Ng LC, Lee JM, et al.; Singapore Zika Study Group. Outbreak of Zika virus infection in Singapore: an epidemiological, entomological, virological, and clinical analysis. Lancet Infect Dis. 2017;17:81321. http://dx.doi.org/10.1016/S1473-3099(17)30249-9

15. Guindon S, Dufayard JF, Lefort V, Anisimova M, Hordijk W, Gascuel O. New algorithms and methods to estimate maximumlikelihood phylogenies: assessing the performance of PhyML 3.0. Syst Biol. 2010;59:307-21. http://dx.doi.org/10.1093/sysbio/ syq010

Addresses for correspondence: Jonathan H. Epstein, EcoHealth Alliance, $460 \mathrm{~W}$ 34th St, New York, NY 10001, USA,; email: epstein@ecohealthalliance.org

\section{EID Podcast:}

Nipah Virus Transmission from Bats to Humans Associated with Drinking Traditional Liquor Made from Date Palm Sap, Bangladesh, 2011-2014

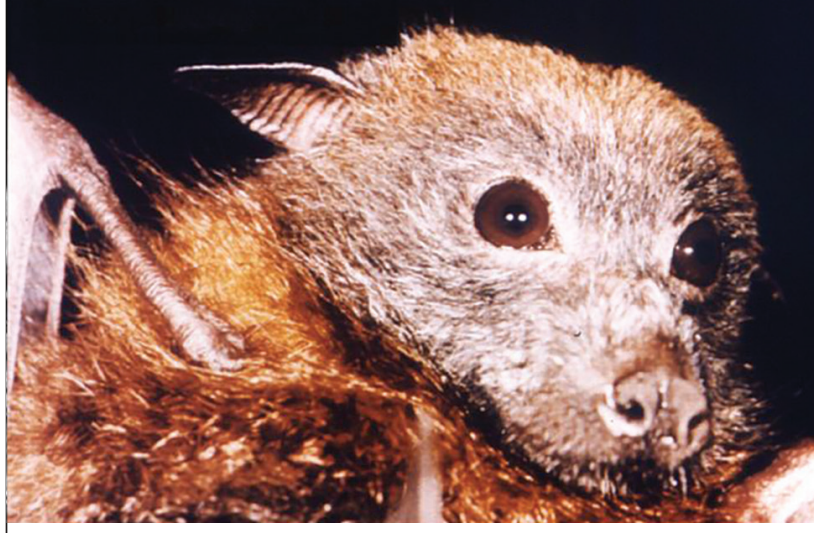

Nipah virus (NiV) is a paramyxovirus, and Pteropus spp. bats are the natural reservoir. From December 2010 through March 2014, hospital-based encephalitis surveillance in Bangladesh identified 18 clusters of NiV infection. A team of epidemiologists and anthropologists investigated and found that among the 14 case-patients, 8 drank fermented date palm sap (tari) regularly before their illness, and 6 provided care to a person infected with NiV. The process of preparing date palm trees for tari production was similar to the process of collecting date palm sap for fresh consumption. Bat excreta were reportedly found inside pots used to make tari. These findings suggest that drinking tari is a potential pathway of NiV transmission.

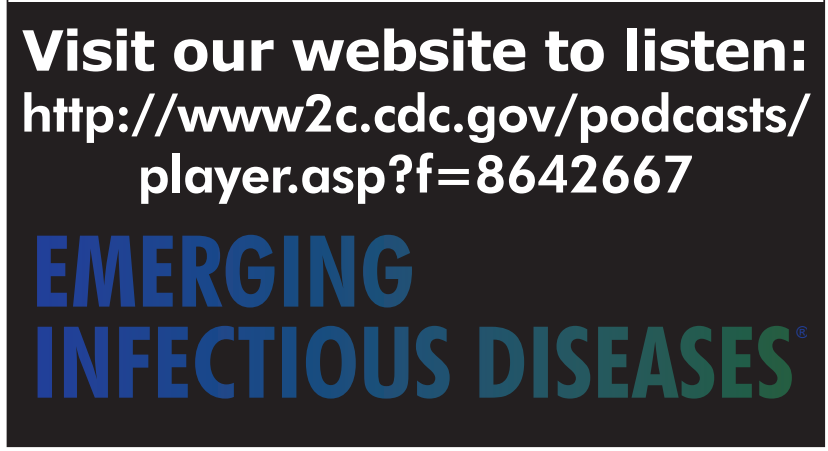

